Olena Liubkina,

Ph.D., Associate Professor, Taras Shevchenko National University of Kyiv, Ukraine

Tetiana Murovana,

Ph.D., Associate Professor, Taras Shevchenko National University of Kyiv, Ukraine

Alina Magomedova,

Ph.D., Taras Shevchenko National University of Kyiv, Ukraine

Evangelos Siskos,

Dr.Sc., Professor, University of Western Macedonia, Greece

Liudmyla Akimova,

Dr.Sc., Associate Professor, National University of Water and Environmental Engineering, Ukraine

\title{
FINANCIAL INSTRUMENTS OF STIMULATING INNOVATIVE ACTIVITIES OF ENTERPRISES AND ITS IMPROVEMENTS
}

\begin{abstract}
The article analyzes the importance of innovations as one of the main factors influencing the competitiveness of enterprises and economies of the world. The study is based on the author's empirical research, grounded on the methodology of analysis of empirical data. The survey was carried out among legal entities and separate departments which operate regardless of its type. The study aimed to determine the importance of financial factors in limiting innovation activity and its potential in stimulating the innovation activity of enterprises. A survey was carried out among the enterprises on the factors that significantly influenced their decision to develop innovative projects or constrained implementation of innovation activities. The key challenges of innovation activity of enterprises were analyzed (law barriers, supply-side barriers, demand-side barriers, barrier on the demand and supply interface, lack of identified priorities, challenges of commercialization of the results of scientific and technical work, as well as weak development of infrastructure, labour problems). The research was also carried out by studying features of using financial instruments to stimulate innovation activity of enterprises, analysis of economic indicators characterizing the innovative activity of enterprises, analysis of strengths and weaknesses of innovation projects, as well as improvement of financial instruments for stimulating the implementation of innovations at enterprises. Based on the conducted research, long-, medium- and short-term directions of financial support of innovative activity were determined. Financial instruments of stimulation innovation activity of enterprises are improved based on the analysis, taking into account socio-economic, political and other particular features of country's development where such projects are implemented; studying the experience of implementing real innovative projects, analyzing strengths and weaknesses of these projects, feasibility of implementing similar projects under such conditions.

Keywords: innovation, innovation ecosystem, innovative activities, investment, simulation of innovative processes, financial instruments.
\end{abstract}

Introduction. Increasing competitiveness of higher education quality as a determinant factor in the socio-economic development of countries of the world becomes more and more important under current conditions of globalization. The United States, Singapore, Germany, Switzerland and Japan have been recognized as the most competitive countries according to The Global Competitiveness Report of the World Economic Forum 2018. (Figure 1). 12 indicators which cover all spheres of socio-economic relations are taken into consideration when determining the global competitiveness index, such as quality of institutions, infrastructure, macroeconomic stability, health and elementary education, higher education and vocational training, efficiency of the market of goods and services, efficiency of the labour market, development of financial market, level of technological development, size of the domestic market, competitiveness of companies, innovation potential. The index is compiled based on information open to the public, as well as based on opinions of several thousand experts from more than 100 countries of the world.

Cite as: Liubkina, O., Murovana, T., Magomedova A., Siskos, E. \& Akimova, L. (2019). Financial Instruments of Stimulating Innovative Activities of Enterprises and Their Improvements. Marketing and Management of Innovations, 4, 336-352. http://doi.org/10.21272/mmi.2019.4-26 
Liubkina O., Murovana T., Magomedova A., Siskos E. \& Akimova, L. Financial Instruments of Stimulating Innovative Activities of Enterprises and Their Improvements

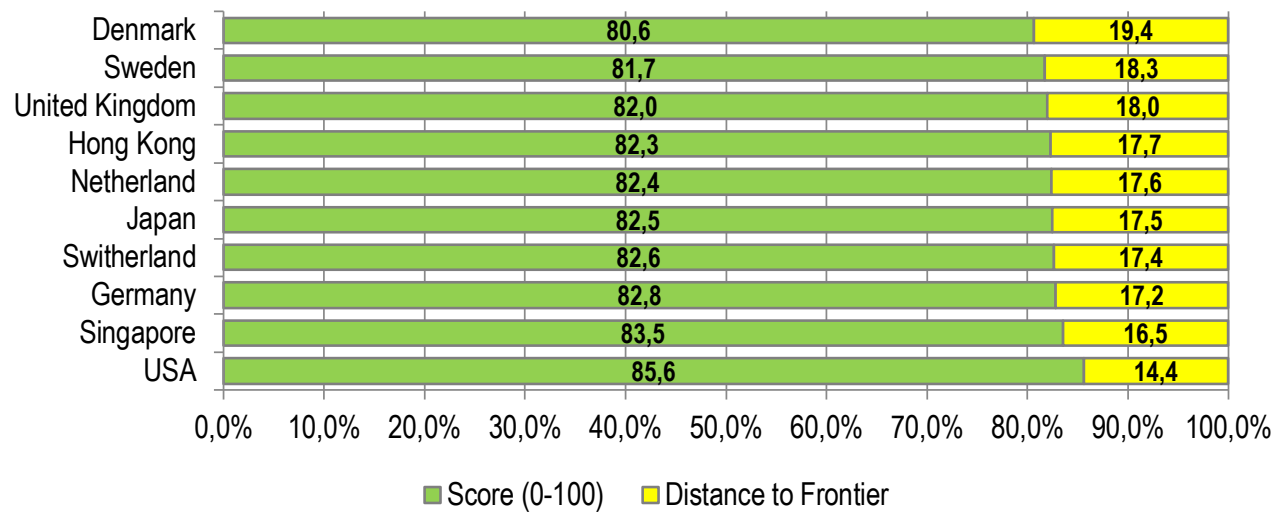

Figure 1. Global Competitiveness Index, 2018

Sources: World Economic Forum, 2018.

In this case, reducing transparency threatens the growth and prosperity of the country. Considering this, measures of monetary stimulation should be accompanied by reforms in the field of state regulation of entrepreneurial activity. At the same time, stimulation of business activity and investment in innovation should play a priority role, as well as the development of infrastructure, entrepreneurial skills and access to international markets. Experts from the World Economic Forum point out corruption, political instability, inflation, ineffective government policies and access to finance among the most problematic factors affecting business development. Besides, crime, social development and low level of skills of employees might affect the weakness of competitiveness. Under such circumstances, issues of the research and improvement of financial mechanisms of stimulating innovation activity of enterprises become extremely important and relevant. According to the Global Competitiveness Report 2017-2018, Ukraine cut 6 points in the ranking and ranked 81st out of 137 surveyed countries. Bhutan was ranked one position lower (82nd place), while Brazil ranked 80th. Switzerland has topped the ranking for the ninth consecutive year (Figure 2). The United States is in the 2nd place, Singapore has fallen to the 3rd position. The Netherlands and Germany completed the first five countries.

While Ukraine's overall rating has grown by 4, Ukraine's position has deteriorated in 4 out of 12 criteria: Infrastructure, Higher Education and Training, Labour Market Opportunity and Innovation. Ukraine has worsened its position in the ranking of almost all indicators of the Innovation subindex, except Availability of Scientists and Engineers. The largest fall is noted by the criteria: Quality of Scientific Research Institutions, Company Spending on R\&D, University-Industry Collaboration in R\&D and Government Procurement of Advanced Technology Products.

In 2016, Ukraine was first included in the European Innovation Scoreboard. According to the accepted classification, Ukraine goes into the Modest Innovator group. Its innovation activity is estimated at $34 \%$ of the average European level, and it is the last position in the rating. Ukraine lags by all indicators, except for the Population with Completed Tertiary Education indicators. Employment Knowledge-Intensive Activities indicator is close to the EU average. The lowest indicators are Public-Private Scientific Copublications, Community Designs, Community Trademarks, and Venture Capital Investment. In the dynamics, the value of almost all indicators has not changed significantly, except for the reduction of NonR \& D Innovation Expenditures (-6.5\%) and Sales Share of New Product Innovations (-5.2\%). 
Liubkina O., Murovana T., Magomedova A., Siskos E. \& Akimova, L. Financial Instruments of Stimulating Innovative Activities of Enterprises and Their Improvements

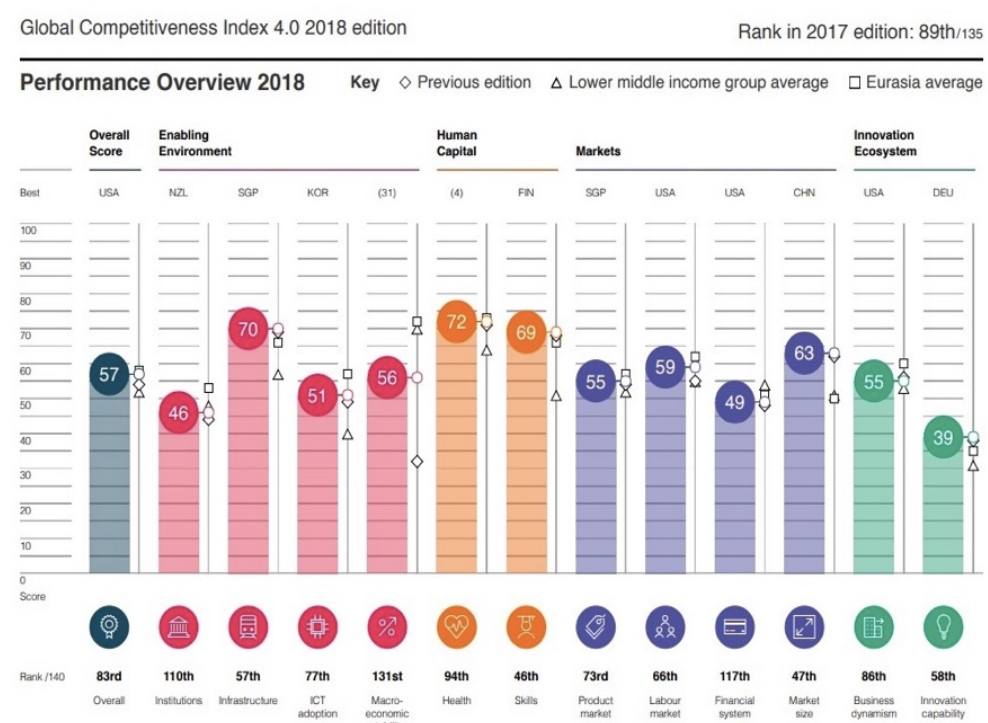

Figure 2. Position of Ukraine in the competitiveness rating in terms of indicators Sources: World Economic Forum, 2018.

The basic system of concepts defining different types of innovation and related processes, as well as the methodology for their measurement, are based on the Laws of Ukraine «On Innovation Activity», «On Scientific and Scientific and Technical Activity», Guidelines on the Collection and Analysis of Data on innovation, methodological recommendations for the survey of innovation in the European Union.

The overall cost of innovation can include the enterprise's costs to innovate something new both to the enterprise and to the market, including internal research, acquisition of R\&D products, machinery, equipment and software, any external knowledge, and other expenses. Although the Cabinet of Ministers of Ukraine approved the Concept of development of the National Innovation System (NIS) in 2009, nowadays, Ukraine's innovation activity is determined by the slow pace of development. National innovation system just begins to form as a market-type system. Slowly but still there are new innovative institutions that can provide innovative products. To a greater extent, certain positive trends that appear in this context are not due to a well-balanced state policy to support and develop innovative processes but through self-regulating market mechanisms. It is worth noting the main participants taking direct part in the development of the national innovation system: institutions of higher education; scientific institutions; inventors; Ministry of Education and Science of Ukraine; Ministry of Economic Development; central executive authorities and national academies of sciences; entrepreneurs, innovative business; investors (venture funds, business angels); innovative infrastructures (technology transfer centres, business incubators, etc.). Coordinated activity and synchronous development of the key players will increase the level and determine the vector of innovation development of the country. However, financial support and stimulation of innovation is the most significant barrier to innovation in the country. The study aims to improve financial instruments for stimulating the innovation activity of enterprises based on the socioeconomic, political and other features of the country's development in which such projects are implemented, studying the experience of implementing real innovative projects, analyzing strengths and weaknesses of these projects and feasibility of implementing similar projects under such conditions. In accordance with the stated aims, the following tasks are defined:

- studying features of using financial instruments to stimulate innovation activity of enterprises; 
- analysis of economic indicators characterizing the innovative activity of enterprises;

- analysis of strengths and weaknesses of innovation projects, as well as improvement of financial instruments for stimulating the implementation of innovations at enterprises.

Literature Review. The problem of activating innovation, in particular, due to the creation of sufficient financial support and financial incentive system, has been relevant for many decades. Almost every country has accomplished its scientific achievements in this area; their significance in the global context depends not only on their scientific quality but also on possibilities of publishing and presenting research, the universality of the problems, etc. Researches of many scholars are devoted to the study of the innovative model of economic development, the influence of innovations on economic growth, labour productivity, strategies and mechanisms for the formation of innovative competitive advantages. Innovations as an innovation process are considered in the works (Nieschlag et al., 2012, Zizlavskiy, 2013). Other authors treat innovation as a process of obtaining a result from innovations (Voynarenko et al., 2017, Nieminen, 2018). The combination of the two approaches can be found in the works of scientists who interpret innovations as a process of changing the state, so to say, the transition from innovation to the result of its introduction (Azgaldov and Kostin, 2008; Morris, 2019). Summarizing the existing concept of innovation, we can state that the main feature of innovation is a focused and stable socio-economic change in the state of the environment for its implementation and realization. Science needs to find out ways of solving economic problems of the development of such a global socio-economic phenomenon as scientific and technical activity and its support under conditions of formation of an information society. Besides, under current conditions, special importance should be given to state scientific and technical policy, in particular, to improve the legislative provision of the development of the scientific and technical sphere. Under such conditions, informatization process and implementing electronics in production and consumption of material and ideal goods will have the greatest influence on accelerating the development of the markets for science-intensive products. (Vakulenko V. and Zhylinska O., 2014). State regulation plays an important role in the processes of stimulating the innovation activity of enterprises. There are two strategic approaches among methods of such stimulation: strategies aimed to promote accessibility in the development of a regional innovation system (Andersson, Karlsson, 2002) and strategies aimed to analyze the competitive advantages associated with the availability of specific local resources (Maillat and Ke'bir, 2001). Besides the existing research, some researchers (Doloreuxa and Parto, 2005) use strategies of regional innovation systems as an analytic basis for the formation of innovation policy. However, approaches that use these frameworks remain controversial on key issues such as the territorial dimension of innovation (regional affiliation) and the role played by «institutions» in causing and maintaining regional innovation systems.

Analyzing financial instruments for stimulating the innovation activity of enterprises, it is worth paying attention to the study of the impact of formal standards and regulation on the effectiveness of innovation companies, taking into account the factors of uncertainty in the market. Some scholars (Blinda et al., 2017) claim that official standards and regulatory principles have different effects. The results of the study showed that formal standards lead to a reduction in the efficiency of innovations in markets with low uncertainty and state regulation has a reciprocal effect. In cases of high market uncertainty, regulation leads to a reduction in the effectiveness of innovation while formal standards have a reciprocal effect. The modern model of innovation activity shows that one of the key factors in the success of innovative enterprises is the proper implementation of new market decisions under the appropriate state regulation (Marc de Jong et al., 2013). The problem of differentiation of innovations is connected with several issues related to the process of spreading and promotion of innovations in the market under the context of the implementation of appropriate competitive advantages (Cherroun Reguia, 2014). It is generally recognized that the power of innovation differentiation is an important determinant of productivity. Considering this, problems related to the effective differentiation of innovations in entrepreneurship have been presented 

Activities of Enterprises and Their Improvements

and existing problems for their implementation have been analyzed (Norek, 2017). Some publications (Voynarenko et al., 2017) proposed a scientific methodological approach to assessing the effectiveness of the introduction of information technology in the innovative business process which provides gradual accounting of all costs and risks. In this context, an algorithm for managing innovative business processes of enterprises is built, it is also proved that usage of IT ensure the formation of information management system for innovative business processes and construction of an effective mechanism for its implementation. Not enough attention is paid to the applied nature of such research and reality of doing business under difficult economic conditions despite a large amount of scientific research on issues of stimulating innovation activity and its impact on formation competitiveness of the economy. The analyzed studies do not pay a lot of attention to the experience of implementation existing innovative projects, the feasibility analysis of its implementation under certain socio-economic and political conditions of the countries where they were implemented, neither studying the causes of their inefficiency nor taking into account such experience for conducting further researches.

Methodology and research methods. The main methods used during the study were: analysis, synthesis, index method, expert research. Data from the author's empirical studies (including questionnaire surveys) were used during the study. Processing and systematization of the obtained data were carried out with the help of economic and mathematical methods (including methods of correlation analysis). An important place among the methods of analysis of innovation activity of enterprises is a survey method. The objective of the survey was to determine the importance of financial factors in limiting innovation activity, and their potential in stimulating innovation activity of enterprises. The survey was conducted among legal entities and their separate subdivisions that perform activity regardless of its type. The survey was selective and an elaborate questionnaire was used. The information about the factors hindering the innovative activity of enterprises and on the use of financial methods for stimulating innovation activity was gathered. To assess the significance of innovation activity in the business model of the investigated enterprises and organizations, they were grouped according to the type of innovation behaviour:

- active: enterprises use the results of their current activities to intensify innovation processes to expand market channels and focus on the development of their enterprise;

- adaptive: oriented to maintain the existing sales volume, activation of innovative processes is used as a compulsory means of keeping current performance indicators and adapting to the challenges of the business environment;

- passive: enterprises expect a decline in key performance indicators or do not see prospects for expansion of their sales market or diversification of activities.

A survey was carried out among these enterprises on the factors that significantly influenced their decision to develop innovative projects or constrained implementation of innovation activities.

Results. Modern Trends in the Development of Innovation Activity in the World. In modern conditions of socio-economic development of the country, leadership in the world markets belongs to the countries whose economic development is dominated by innovation activity. There is always a demand for innovations, so they are and should be a priority in the policy of any country that is constantly striving for economic development. In most developed countries, the regulation of innovation activity takes place through different levels of government participation. At that, the key role in the processes of innovation activity is given to the subjects of entrepreneurship (transnational corporations, representatives of large, medium and small businesses). At present, it is possible to highlight the main directions of stimulation of innovative activity of developed countries: implementation of large and perspective target projects that cover all stages of the scientific and production cycle, usually with a significant part of scientific and innovative potential, creation of a favourable innovation environment, development of innovations through the development of innovation infrastructure, sensitive to the achievements of world scientific and 

Activities of Enterprises and Their Improvements

technological progress, coordination and interaction of various economic sectors in the field of science and technology, distribution of innovations. The USA remains one of the most innovative countries in the world. In the innovation activities of the USA, a significant role belongs to state regulation. In such conditions, great attention is paid to the stimulation of public-private partnership, the cooperation of research organizations and business, as well as international cooperation in innovation activities. To fund fundamental and applied for work, the state creates special funding programs. Also, in the USA, such a kind of financing of innovation activity as venture financing is widespread. Many venture companies fund projects that are most successful around the world (such as Apple, Microsoft, Google, etc.). To the most innovative companies in the USA, we may include companies such as Apple, Google, Microsoft, Tesla Motors, IBM.

The European Union uses many investment attraction tools to finance innovation activity. Among them are direct government funding, primarily through grants, loans, subsidies, etc.; creation of infrastructure for innovation activity; tax incentives, special schemes for supporting risk financing, provision of state guarantees. All countries of the world have virtually different tools of innovation policy. In Europe, the joint government decisions of the EU member states have formed several institutions that provide direct support to the innovation process: European Investment Bank, European Investment Fund, Opening Capital, Euroteks Capital, small business support programs. From successful projects, the state receives a significant replenishment of the budget in the form of taxes. In the UK, a series of activities aimed at stimulating research and development in the business sector takes place. The key mechanism of state support for the development of science and high technologies is the implementation of tax privileges for organizations involved in research and development. An important role in the development of innovation policy in the UK is the creation of information support for innovation activity. Along with the mentioned support measures in the UK, it is necessary to note the active form of the infrastructure basis for conducting innovation activity. In particular, companies that provide consulting and service in the field of technological development have become widespread. In recent years, many states have been using mixed forms of innovation promotion, which includes various options for funding and taxing high-risk risk projects, contract research with external firms and investment in restoring production processes. In Germany, they were called «indirect specific aid», which is a combination of direct and indirect state support of innovative active firms involved in the implementation of state scientific and technical programs. Up to $80 \%$ of the research activities of institutions of higher education are carried out at the expense of funding, which is allocated through grants of large scientific societies. Besides, the government provides financial support for the development of long-term and risky research in the field of scientific-technical and production-economic activities.

A striking example is Finland, where the so-called «scientific-industrial incubators» or «business incubators» operate. In such incubators, future commercially attractive inventions pass from an idea to manufacturing of competitive products, which has a high demand in the global market for goods and services. These incubators combine universities, research and production centres, lawyers and managers, venture companies into one single sector. The main form of providing budget funds is the provision of free subsidies, grants for research projects on a competitive basis. In Finland, like in most developed countries, there are no privileges for those who create and implement innovative developments. Switzerland is one of the leaders among the countries that implement innovations. At the same time, a high coefficient of innovation efficiency suggests that all innovative resources are involved in the best way. As the most innovative company in Switzerland, Roche holding pharmaceutical company should be highlighted. Roche invests a large amount of money in its laboratories and develops new drugs. The main instruments for funding science and innovations in Japan are subsidies to state universities and state-owned trust funds to support research. Among the organizational support, measures are the following: the creation of international centres for research capable of attracting well-known and talented foreign scientists to their 

Activities of Enterprises and Their Improvements

work, training of qualified administrative and support staff for scientific centres, including specialists in work. In the innovation activity of Japan, there is a tendency of development of the public-private partnership, international cooperation, the significant manifestation of which is the intensification of efforts to develop international innovation cooperation, including at the regional level. Over the past few years, Japanese auto giant Toyota has patented more than 7,000 new technologies in the field of engine construction.

As an example of innovative development, it is worth noting South Korea where the major «engines» of economic growth are considered to be large industrial groups. The state actively supports their desire to diversify their activities based on science-driven technologies to increase the share of exports in the total volume of their products. Korea is distinguished by developed advanced technologies, and the largest Korean company Samsung is one of the world's most famous manufacturer of home appliances, mobile phones, tablets, TV sets and continuously refines the entire line of its products. An innovative development model needs at least $2 \%$ of GDP to finance science. Countries that have achieved high rates of economic growth through the innovation factor (USA, UK, Germany, Finland, Japan, Korea, etc.) meet this requirement. Stimulation of innovation activity, in any case, requires financial investments, development of innovative cooperation. For developed countries, the typical features of the development of innovation activity are: providing tax privileges, preferences, subsidies, simplifying administrative procedures, supporting enterprises investing in poorer regions of the state, setting up technological parks, etc.

The essence of financial instruments to stimulate innovation activity. The next measures should be considered under financial instruments to stimulate innovation activity - withdrawal of innovation activity out of the general taxation; implementation of new principles and mechanisms of partnership between the state and private business (direct state financing, direct state loans, non-state loans, state guarantee of loans, non-state guarantees of loans); strengthening export of the domestic capital with the help of tax instrument. State contracts from various government organizations to conduct R\&D are one of the main financial instruments to support innovative projects for many countries. Such contracts require thorough coordination of all main characteristics of innovation projects, expected results, deadlines and costs involved. An important role in stimulating innovation activity is played by the tax system. Activities of enterprises which is aimed to implement results of research and development works as well as scientific researches into its production processes should be able to tax incentives. The goal of tax incentives is to the relief tax burden, find effective methods to reducing tax liabilities and as a result, increase the profitability of financial and economic activity, increase the efficiency of enterprise production activities. The financial support system for innovation activity is derived from geopolitical, socio-political and macroeconomic processes. The overall cost of innovation can include the enterprise's costs to innovate something new both to the enterprise and to the market, including internal research, acquisition of R\&D products, machinery, equipment and software, any external knowledge, and other expenses. Expenditures for research and development are the actual costs of carrying out research and development regardless of the source of funds, including both current and capital costs (excluding the number of depreciation deductions for the full restoration of fixed assets). The specified amount of expenses does not include expenses for the performance of works (services) that are not related to research and development, as well as paid services to the population. Innovation Ecosystem: Key Financial Figures. As of the end of 2017,759 industrial enterprises carried out innovation activities in Ukraine, which is 9\% less than in 2016 and $8.5 \%$ - than in 2015. Geographically the most innovative enterprises are of Dnipropetrovsk, Kharkiv, Lviv, Zaporizhzhia, Kyiv, Odesa, Ivano-Frankivsk, Kirovohrad, Vinnytsya regions and the city of Kyiv. The lowest indicator of innovation activity of enterprises was recorded in Khmelnytskyi, Rivne and Chernivtsi regions. According to the types of economic activity, the largest share of innovation-active enterprises is at the production of food, beverages, tobacco products $-22.0 \%$ and the smallest is at the sector of production of other vehicles than electrical equipment and machinery $-4.3 \%$. In 2017 the amount of 
Liubkina O., Murovana T., Magomedova A., Siskos E. \& Akimova, L. Financial Instruments of Stimulating Innovative Activities of Enterprises and Their Improvements

innovation financing has decreased to $\$ 337.69$ million which is almost $60 \%$ less than in 2016 and $34 \%$ than in 2015. Investment of own funds of business entities remains the main in the structure of sources of innovation financing. The table presents a comparative description of sources of financing of innovation activities in Ukraine in 2010 and 2017 (Table 1). The share of the state budget, local budget, domestic investors increased in the general structure of financing of the development of innovation activity of enterprises in Ukraine. Instead, the volume of investment of innovative activity of enterprises from foreign investors and the share of loans for innovation development decreased significantly. According to the table, financing of innovation activity in 2017 , as compared to 2010 , increased by $13.32 \%$.

Table 1. Comparative characteristics of sources of financing of innovation activity in Ukraine in 2010 and 2017

\begin{tabular}{|c|c|c|c|c|c|}
\hline Sources of financing & 2010, thousand \$ & \begin{tabular}{|c|}
$\begin{array}{c}\text { Share in the general } \\
\text { structure, } \%\end{array}$ \\
\end{tabular} & \begin{tabular}{|c|}
2017 \\
thousand \$ \\
\end{tabular} & \begin{tabular}{|c|}
$\begin{array}{c}\text { Share in the general } \\
\text { structure, } \%\end{array}$ \\
\end{tabular} & $\begin{array}{l}\text { Growth } \\
\text { rate, } \%\end{array}$ \\
\hline Total & 297981,30 & 100,0 & 337686,56 & 100,0 & 113,32 \\
\hline Own funds & 176860,58 & 59,3 & 285337,56 & 84,5 & 161,33 \\
\hline State budget & 3222,26 & 1,1 & 8418,19 & 2,5 & 261,25 \\
\hline Local budget & 209,77 & 0,1 & 3540,17 & 1,0 & 1687,67 \\
\hline Extrabudgetary funds & 34,41 & 0,0 & 11,54 & 0,0 & 33,55 \\
\hline Domestic investors & 1148,84 & 0,4 & 10114,33 & 3,0 & 880,39 \\
\hline Foreign investors & 89310,95 & 30,0 & 3991,59 & 1,2 & 4,47 \\
\hline Loans & 23189,17 & 7,8 & 22017,22 & 6,5 & 94,95 \\
\hline Other sources & 4005,33 & 1,3 & 4256,00 & 1,3 & 106,26 \\
\hline
\end{tabular}

Sources: Ukraine. Science, 2017.

However, this situation is associated with a significant reduction in financial investments in the development of innovative enterprises in 2017. From 2010 to 2017, the lowest indicators of financing innovation were recorded in 2013 - at \$ 285.03 million, and in 2017 - at \$ 337.69 million. Figure 3 shows the growth rate of innovation activity financing of enterprises in Ukraine by sources of origin, which indicates that during the analyzed period the role of local budgets in support has increased dramatically.

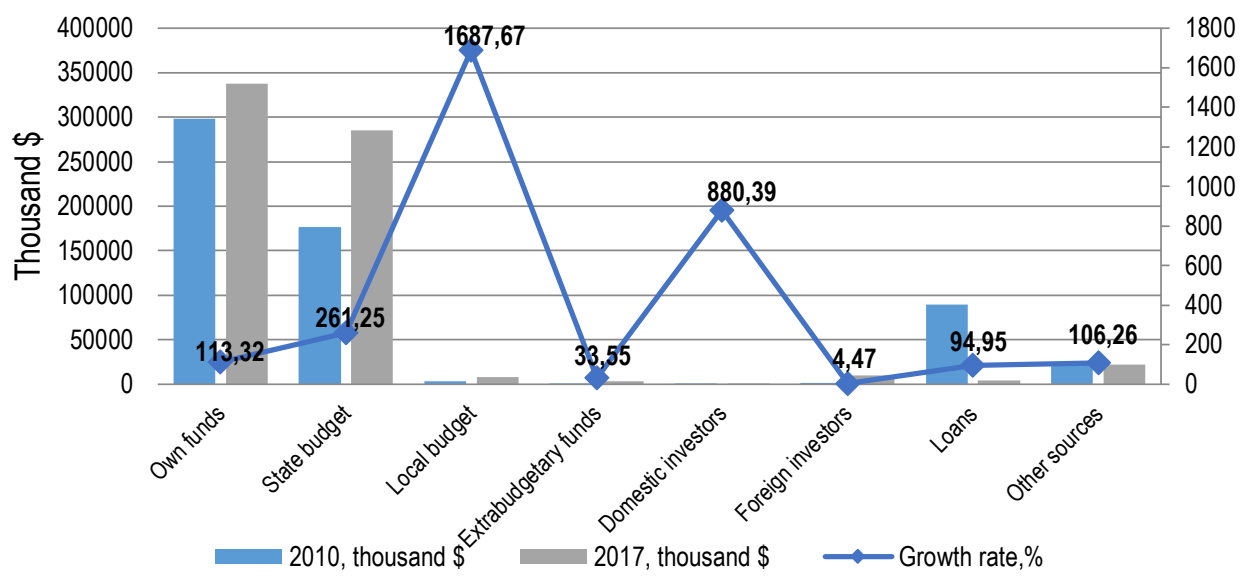

Figure 3. Sources of financial support of innovation activity in Ukraine in 2010 and 2017 Sources: Ukraine. Science, 2017. 

Activities of Enterprises and Their Improvements

The average share of enterprises engaged in innovation activity in Ukraine ranged from $11.2 \%(2006)$ to $18.9 \%$ (2016). In the last five years, this share was more stable: the deviation from the average level in the economy was within $1 \%$. The share of innovation-active industrial enterprises from the total number of industrial enterprises with an average number of employees of 50 persons or more was slightly lower and amounted to $16.2 \%$ in 2017 . This indicator decreased compared with $2016(16.6 \%)$, but generally corresponds to the level observed over the last 5 years. $39.8 \%$ of the mentioned enterprises exported innovative products totalling to $\$ 7.4$ million. Almost every fourth company sold a new product at the market, amounting to $\$ 166.7$ million (41.5\% - for export). A significant number of enterprises $(83.8 \%)$ sold products that were new exclusively for the enterprise totalling to $\$ 488.9$ million $(27.7 \%$ of such products were exported). According to the geographical location of partners, $32.4 \%$ of innovative enterprises cooperated with enterprises of Ukraine, $5.7 \%$ - in European countries. It should be noted that there is a link between the size of the enterprise and its level of innovation since for introduction of innovation it is necessary to have a certain number of personnel involved in the implementation of research and development (hereinafter - R\&D). Accordingly, the highest share of both technologically innovative and non-technologically innovative enterprises was among large enterprises $(31.4 \%$ and $28.1 \%$, respectively). The highest share of innovative enterprises was at the enterprises of information and telecommunications $(22.1 \%)$, manufacturing $(21.9 \%)$, financial and insurance activities $(21.7 \%)$ and activities in the field of architecture and engineering (20.1\%). The share of enterprises that cooperated with scientific organizations was $8.4 \%$. Financial Aspects of Innovation Activity of Enterprises (on the example of enterprises of the Kyiv region). According to official statistics (State Statistics Committee of Ukraine, 2017), 132 innovation active enterprises worked in the Kyiv region in 2017: in. Kyiv - 95 (20.7\% of all enterprises) and in the Kyiv region -37 (11\% of all enterprises). With this indicator, Kyiv ranks 7 th among the local units of Ukraine (after Ivano-Frankivsk, Kropyvnytskyi, Mykolaiv, Ternopil, Kharkiv and Cherkasy regions) and Kyiv region is the $17^{\text {th }}$ among 25 . However, in terms of costs of innovation activities, Kyiv ranks first in Ukraine ( $\$ 68.9$ million), and the Kyiv region has the $9^{\text {th }}$ place $(\$ 10.7$ million). With the volume of sales of innovative products, Kyiv and Kyivska oblast occupies the $3^{\text {rd }}$ and $4^{\text {th }}$ place $(\$ 59.9$ million and $\$ 28.5$ million, respectively).

Most innovative enterprises in the region actively introduced innovative processes or created innovative products (126 out of 132 enterprises); 23 enterprises are engaged in activities in the field of resource-saving technology: production of alternative fuels from wood waste, organic, bio-organic and other wastes, biogas production, batch production of heat pumps, solar collectors, heat points and modular resource-saving mini-boilers, and manufacturing modern biotechnology-based medical forms. The peculiarity of Kyiv and the Kyiv region is the high level of infrastructure development, financial in particular. There are offices of almost all banks, financial and investment companies in Kyiv. There is a significant number of high-ranking universities there. Due to this, international innovation corporations open their offices (Bayer, Global Logic, Microsoft, Luxoft, etc.), and sometimes R\&D centres (Samsung, Etera).

Significance of innovation activity in the business model. 35 enterprises and organizations were selected for the survey on the following types of activities: ICT-industry - 5 (14.3\%); refining - 4 (11.4\%); trade $-4(11.4 \%)$; research activity $-3(8.6 \%)$; production of agro-industrial products $-3(8.6 \%)$; consumer goods - $3(8.6 \%)$; machine building - $3(8.6 \%)$; construction - $2(5.7 \%)$; manufacture of chemicals and chemical products - $2(5.7 \%)$; manufacture of pharmaceuticals - $2(5.7 \%)$; finance $-1(2.8 \%)$; communication - $1(2,8 \%)$; others (Chamber of Commerce and Industry, provider between investment and financial institutions) $-2(5,7 \%) .31$ institutions have the experience of carrying out innovation, $R$ \& $D$ or related activities (88.6\%). The objective of the survey was to determine the importance of financial factors in limiting innovation activity, and their potential in stimulating innovation activity of enterprises. 
Liubkina O., Murovana T., Magomedova A., Siskos E. \& Akimova, L. Financial Instruments of Stimulating Innovative Activities of Enterprises and Their Improvements

The survey was conducted among legal entities and their separate subdivisions that perform activity regardless of its type. The survey was selective and an elaborate questionnaire was used. The information about the factors hindering the innovative activity of enterprises and on the use of financial methods for stimulating innovation activity was gathered. To assess the significance of innovation activity in the business model of the investigated enterprises and organizations, they were grouped according to the type of innovation behaviour: active, adaptive and passive (Table 2).

Table 2. Types of Investment Behaviour of the Enterprise

\begin{tabular}{|c|c|c|}
\hline Innovative Behaviour & Description & Number of Enterprises \\
\hline Active & $\begin{array}{l}\text { Enterprises use the results of their current activities to } \\
\text { intensify innovation processes to expand market } \\
\text { channels and focus on the development of their } \\
\text { enterprise }\end{array}$ & $\begin{array}{c}10 \\
\text { (mostly ICT-industry, } \\
\text { pharmaceuticals and chemical } \\
\text { industry) }\end{array}$ \\
\hline Adaptive & $\begin{array}{l}\text { Enterprises oriented to maintain the existing sales } \\
\text { volume, activation of innovative processes is used as a } \\
\text { compulsory means of keeping current performance } \\
\text { indicators and adapting to the challenges of the } \\
\text { business environment }\end{array}$ & $\begin{array}{l}9 \\
\text { (mostly chemical industry, } \\
\text { manufacture of consumer goods, } \\
\text { construction, machine building) }\end{array}$ \\
\hline Passive & $\begin{array}{l}\text { Enterprises expect a decline in key performance } \\
\text { indicators or do not see prospects for expansion of } \\
\text { their sales market or diversification of activities }\end{array}$ & 12 \\
\hline
\end{tabular}

Sources: developed by the authors.

A survey was carried out among these enterprises on the factors that significantly influenced their decision to develop innovative projects or constrained implementation of innovation activities. Table 3 shows the distribution of enterprise responses as a percentage of the frequency of their mention (respondents could name a few reasons).

Table 3. Survey questionnaire on the factors that significantly influenced the decision of enterprises to develop innovative projects

\begin{tabular}{|c|c|c|}
\hline Examples of answers & $\begin{array}{c}\text { Number of enterprises/weight, } \\
\%\end{array}$ & $\begin{array}{c}\text { Number of } \\
\text { references }\end{array}$ \\
\hline No compelling reasons to innovate & $21 / 60,0 \%$ & 19 \\
\hline $\begin{array}{c}\text { including } \\
\text { Low demand for innovation in the market }\end{array}$ & & 10 \\
\hline Lack of good ideas or opportunities for innovation & & 8 \\
\hline $\begin{array}{c}\text { Because of unsuccessful previous innovation } \\
\text { The possible introduction of innovation was hampered by } \\
\text { significant factors }\end{array}$ & $14 / 40,0 \%$ & 14 \\
\hline $\begin{array}{c}\text { including } \\
\text { Lack of own funds }\end{array}$ & & 12 \\
\hline Excessive costs for innovation & & 9 \\
\hline $\begin{array}{c}\text { Difficulties in obtaining state aid or subsidies for } \\
\text { innovation }\end{array}$ & & 6 \\
\hline Lack of credits and private capital & & 3 \\
\hline Lack of partners for cooperation & & \\
\hline
\end{tabular}

Sources: developed by the authors.

It is worth noting that these results are estimated for the Kyiv region and the group of the selected enterprises. The situation may vary on the level of activity and even on the enterprise level, and also 

Activities of Enterprises and Their Improvements

considering that the list and significance of the hindering factors may depend on the age, size, industry and innovation of the enterprise. The next part of the questionnaire included the study of the stimulating potential of financial leverage. The results of the answers provided were as follows:

1. The majority of respondents called the achievement of macro-financial stabilization as the main driver of investment activity in Ukraine: stabilizing the economy, reducing inflation, stabilizing the currency rate, creating a favourable investment climate for attracting foreign investors; creating conditions for small and medium-sized business development. «Investment in Ukraine will come only when investors already working in the country feel comfortable. Then they will send the message to the world that Ukraine can and should be invested in. Therefore, all government efforts should be aimed at supporting local and international investors who are still testing the Ukrainian market. Nobody believes in the declarations of prospects, they believe only in real actions», a representative of the Investment Agency in Kyiv said.

2. Liberalization of currency exchange legislation, facilitation of foreign economic activity for domestic business and science representatives with foreign companies were the second in the number of references. At the same time, some respondents expressed concern about the openness of the national innovation system. A representative of an international IT office said: «If a team with promising research appears in Ukraine very quickly the intellectual product is registered somewhere in Switzerland, Holland or Cyprus, the device itself is (nominally) produced in China because of its cheapness, and the team can physically appear in the United States of America. Foreign companies do not want to just fund some research in Ukraine. They seek to obtain full intellectual property rights thus discriminating against domestic scientists. We need to encourage both the business and Ukrainian inventors to produce the final product in Ukraine to receive profits and pay taxes here».

3. The next financial leverage to stimulate innovation was the creation of a system of incentives and financial support for innovation, in particular: introduction of programmes to stimulate innovation by businesses; introduction of tax incentives for companies conducting R\&D; financial support for spin-offs and start-ups, for example, loans from state banks on preferential terms or exemptions. One of the respondents stated: «The government should act for innovators in 2 roles: as a customer of services and as a facilitator in attracting international investors to the country. It is important to support not only startups but also those who invest or are planning to invest in Ukraine. It will become an additional catalyst for the arrival of new investors in Ukraine». In this context, the majority of respondents expressed the view that the world and European experience in stimulating innovation should be more actively implemented.

4. Many respondents noted the insufficient level of applicative knowledge received by students in domestic universities. So the representative of the company that develops and supports integrated webprojects, RESTful Web-services and JavaScript-applications said: «Domestic universities give background knowledge that forms a broad outlook and allows to think in a non-standard way, but the graduates lack information on the specific business needs». A representative of a company working in the field of heavy engineering has mentioned a case of successful implementation of innovation initiated by a representative of science: «One day a scientist came to Zaporizhstal and said: «I have an invention that will allow you to reduce electricity consumption several times. To run it you need to stop your open-hearth furnaces». He was considered original because open-hearth furnaces are hardly ever stopped. Later, the inventor found a businessman and he asked his question differently: «Are you going to stop the furnaces for repair?» He managed to negotiate with the CEO, and the invention was successfully transformed into innovation. But it does not work as a system: research and production institutions lack links. The idea needs to be "packed», sold, invested quickly, thus, enabling the invention to become an innovation». At the same time, being a scientist in Ukraine is not prestigious and success in research and discovery do not entail any corresponding material reward. Among the ways to overcome the gap between business and education could be the financing of official mutual training of representatives of state universities and business representatives; increasing the funding of science; promoting commercialization of scientific institutions; 
Liubkina O., Murovana T., Magomedova A., Siskos E. \& Akimova, L. Financial Instruments of Stimulating Innovative Activities of Enterprises and Their Improvements

financial support for business development at universities (for example, by undergraduate and postgraduate students).

IT sector is the main growing point of innovation in Ukraine's economy. Ukraine is now one of the leading European and global IT outsourcing hubs. Besides, Ukraine is emerging as an R\&D destination for many global companies. The export volume of Ukraine's software development and IT services reached at least $\$ 2.5$ billion in 2015, showing double-digit growth year after year. The US market is the main destination with an estimated $80 \%$ volume of exported services. The country's political turbulence has had little impact on the existing activity of most industry players but remains an obstacle to stronger growth. Kyiv is the most popular location in Ukraine for opening an R\&D centre, concentrating over half of all such bases in the country. Other key cities for R\&D activity include Dnipropetrovsk, Lviv, Odesa, Kharkiv (Kharkov) and Vinnytsya. The country boasts more than a thousand outsourcing companies, including small outsourcing shops, over one hundred national and international R\&D shops as well as over two thousand start-up companies. In 2015, the export volume of Ukraine's software outsourcing companies reached at least $\$ 2.5$ billion. Several IT outsourcing companies originating in Ukraine grew into technology giants with offices worldwide. Among these companies is Ciklum, DataArt, Infopulse, Lohika, MiratechandSoftServe. Can be noted the growth of AOG, an IT service company headquartered in Cherkasy (Central Ukraine), which accounts for 5,000 affiliated freelance engineers less than three years after company launch. At the same time, several foreign outsourcing companies like EPAM, GlobalLogic, Luxoft have multiple offices in Ukraine, which now stands as a major R\&D hub for these global IT service providers. In total outsourcing companies employ more than 50,000 engineers (about $60 \%$ of all engineers) who live across Ukraine. Ukrainian software companies offer virtually every possible software services including, but not limited to, software development, web and mobile development, quality assurance and testing, business process outsourcing, dedicated team outsourcing, research and development services, IT consulting and IT security management. The majority of the country's large outsourcing companies offer full-stack solutions while specializing in several industries. Smaller software shops usually focus on a few services like web development and design, mobile app development and testing, working across many industries.

In addition to independently-formed start-ups, the rich expertise of outsourcing and R\&D companies often serves as a platform for start-ups spin-offs and outshoots that originate within big IT companies. Their teams work on initial prototyping separately to establish independent innovative ventures which have a strong technical team and a proof-of-concept. After the Maidan revolution in 2014, the IT community has mobilized: several IT entrepreneurs starting political careers, lobbying and civic initiatives were intensified. Six IT clusters were formed in Lviv, Odesa, Kharkiv, Kyiv, Dnipropetrovsk and Lutsk to foster regional development. In 2017, Ukraine witnessed a record increase in investment in Ukrainian IT - the total investment amounted to 265 million dollars, which was three times more than in 2016 (by 231\%) (The Dealbook of Ukraine, 2018). 44 agreements were concluded, and $90 \%$ of them had the leading foreign investment funds (General Catalyst, IVP, Spark and Almaz Capital), but with the participation of Ukrainian investors. Foreign capital amounted to $96 \%$ of total investment, whereas the distribution of external and local capital had been almost even in 2016 and before. The most open agreements of 2017 were: 110 million dollars investment in Grammarly (from General Catalyst, IVP, and Spark Capital); 30 million dollars in BitFurry (from Credit China Fintech Holdings); 10 million dollars in Petcube (from Almaz Capital, $Y$ Combinator, AVentures Capital, U.Ventures, Digital Future and others); 7 million dollars in People.ai (from Lightspeed Venture Partners, Index Ventures, Shasta Ventures, Y Combinator, SV Angel). Speaking about sources of early funding in 2017, Ukrainian start-ups attracted investment primarily from venture funds $(90 \%)$, as well as from angels (6\%) and on crowdfunding platforms (3\%). Institutional investors were represented by venture funds. Despite their large number in Ukraine, even having Ukrainian founders they are registered outside Ukraine, in the countries with lower taxes and better protected intellectual property. 

Activities of Enterprises and Their Improvements

Exceptions are such local players such as AVenturesCapital and TAVentures. Individual investors (business ange/s) are ready for more risks. Usually, business angels do not advertise their activity. Therefore, it is impossible to estimate the real size of the market for informal investment. Business angel financing is on the rise due to Ukraine's attractive position in the global market of IT and online services.

Crowdfunding is a technology of collective financing of innovative projects through social networks. Ukrainian start-ups more often enter crowdfunding platforms, including Kickstarter and Indiegogo. Their purpose is to search for the first customers and orders, additional PR and market analysis. There are also more experienced projects that have a few successful fundraising campaigns in stock. According to the results of the first 7 months, 2017 has already become one of the richest in successful crowdfunding campaigns in the history of Ukrainian start-ups. Crowdfunding platforms are a great alternative for products at an earlier stage. Besides, the success of the campaign will be an additional argument in subsequent negotiations with potential investors. $83 \%$ of the projects successfully collected the necessary amounts. As of mid-August 2017, Ukrainian innovation raised $\$ 1,895,252$. Kickstarter is a more popular platform among Ukrainian developers, and 27 campaigns (77\% of all projects) were launched on this platform in 2017. In turn, Indiegogo is used as an additional channel for raising funds. Start-ups often practice the parallel launch of promotional campaigns on two platforms. Unfortunately, it is not always possible to determine Ukrainian involvement in the project as almost half of the projects mention the United States as their location. They do so due to their focus on the global market. But in recent years more and more Ukrainian loyalties can be found in the description of the projects. It should be noted that the authors of the project have to pay a certain percentage of commissions to the crowdfunding platform. It usually ranges from 5 to $10 \%$. The infrastructure of the venture industry has been rapidly developing in Ukraine recently. Various investment exchanges and business incubators operating with venture funds are being created. So in 2014, in spite of the military, political and economic instability in Ukraine, UVCA was launched Ukrainian Association of Venture Capital and Direct Investment, which became a member of EVCA (European Venture Capital Association), UAngel - Ukrainian Business Angel Association. There are active and regular platforms for the presentation of innovative projects: Lviv IT Arena, Falling Wall Lab, telecom accelerator VDNG-Tech.

Conclusion. The key challenges of innovation activity in Ukraine are:

1. Law barriers: inconsistency of legislation in the innovation sector, first of all with corporate, investment, tax, social legislation and ineffective legal protection of intellectual property in the country.

2. Supply-side barriers: lack of incentives to encourage public research organizations to engage in innovation-related activities; lack of entrepreneurial and innovative culture in the state research sector; use of research results abroad with more attractive conditions.

3. Demand-side barriers: insufficient level of interest in research and development by economic entities; insufficient awareness and opportunities for small and medium-sized enterprises in the use of innovation; they need to increase managerial powers in new enterprises created by scientists and technologists; lack of vision and understanding by companies of the Ukrainian research organizations' potential; the state authorities' unwillingness to use the results of R\&D for their purposes (for example, as the first buyer of innovation).

4. Barrier on the demand and supply interface: the insufficient experience of using public-private partnerships in the field of innovation; the lack of formal and effective channels for transferring information as for expectations from enterprises to the science and education sector.

5. Lack of identified priorities: due to significant budget constraints, it is necessary to focus the state support on those areas where public research will be most effective in fostering innovation in the private sector.

6. Challenges of commercialization of the results of scientific and technical work, as well as weak development of infrastructure which would provide solutions to specific issues of commercialization of 

Activities of Enterprises and Their Improvements

scientific developments at different stages of its readiness: the vast majority of scientists are not able to monetize their research results due to lack of knowledge of the mechanism of commercialization technological audit, valuation and protection of intellectual property rights, further search of potential buyers and methods of transferring development to consumers.

7. Labour problems: scientific achievements and personnel often become the property of other states and foreign companies; migration of young people and scientists abroad; ageing of scientific personnel; a low salary of a researcher and a reduction in the prestige of science and education workers.

Improvement of financial support for innovation activity. Among the long- and medium-term directions, the following can be distinguished:

1. To revise the approach to providing budget funds for research work and non-commercial investigation. The allocation of funds for their implementation should be based mainly on the competitive principle. The similar method has been approved by the State Fund for Fundamental Research (SFFR). The Fund members and scholarly experts involved in the examination study scientific projects and collectively decide on their possible funding.

2. It is advisable to: review the number of budget allocations used to perform the most effective R\&D at competitions (increase to $1.7 \%$ of GDP); create a National Fund for Research of Ukraine - a special fund for the formation of topics of perspective fundamental research, their financing and ensuring control over the targeted and effective spending.

3. To expand the amount of financing of innovation activity of the commercial direction through the State Development Bank of Ukraine, as the Bank of the 1st level, legally securing the corresponding functions and financial resources. Formally, such a bank has already been created but it has been endowed with neither special status and functions nor with the corresponding capital.

4. It is advisable to create a State Venture Fund which will select and co-finance, with the direct participation of the Development Bank, innovative projects in priority areas for the economic development of the state. Such a fund can also become a co-investor of innovative projects with private venture funds, which will allow them to share risks of project financing.

The venture capital Fund of Funds project is being actively lobbied by representatives of the venture capital industry. The state should not act as a co-investor of this Fund (the financial contribution will be no more than $5-10 \%$ ) but as the guarantor of its activities. The KPI of this project is $-1,000$ innovative companies will further be invested, taking into account that the average check is 500 thousand dollars. Thus, the total capital of the Fund will be half a billion dollars. This model has already been implemented in Europe, America, etc. The Fund will invest in venture funds on a competitive basis, and they will finance more than 3,000 already existing Ukrainian start-ups. Creation of the Fund of Funds will allow attracting investment from large international institutional funds to the Ukrainian investment ecosystem.

5. Bank loans are a relevant form of financing for innovation at the final stage. However, according to the Business Environment and Enterprise Performance Survey (BEEPS), more than half of enterprises in need of financing in Ukraine do not consider the option of a bank loan due to high rates, high overheads, and unofficial payments. At the same time, more than $90 \%$ of the requests of young enterprises were rejected by banks because of non-compliance with the standards of creditworthiness. And, taking into account the strict approach of the NBU to the financial stability of banking institutions, the introduction of IFRS 9 in Ukrainian banks from 2018 will make the standards of creditworthiness even higher. Individual banks offer products for the SME, but not specialized offers to finance innovation. It is viable to elaborate a mechanism for the NBU to conduct lending bids (within refinancing) by banks that provide loans to innovative enterprises at a rate determined by the National Bank of Ukraine (by establishing the margin for banks that provide and continue to serve these loans). In doing so, it is necessary to establish requirements and restrictions on the activities of such banks, which should be stipulated in the loan agreement. 
Liubkina O., Murovana T., Magomedova A., Siskos E. \& Akimova, L. Financial Instruments of Stimulating Innovative Activities of Enterprises and Their Improvements

6. Expand the range of state support. State support of innovative activities in Ukraine is carried out in various forms - direct budget financing, favourable credit, tax and customs policy, creation of the specialized state (communal) innovative financial and credit institutions, provision of state guarantees to commercial banks, which carry out lending of priority innovative projects, etc. Direct funding from the state and local budgets is quite limited and usually refers to a small number of innovative enterprises (2.0-3.0\% of their total number). It should be noted that even these limited funds are not diverted to the state-defined priority directions of innovation activity, many of them are provided to extractive enterprises, low-tech and medium-low-tech industries (metallurgy or chemistry). Among the forms of state financial support are tax incentives; tax credits; accelerated depreciation; raising factors for current R\&D expenditures, which allow reducing the base for income tax calculation; dismissal, which allows companies not to pay at all or to pay individual taxes to a lesser extent. Some benefits are not explicit. For example, the whole IT sector in Ukraine can register its employees as individual entrepreneurs, which results in a reduction of the tax burden on the company.

7. The question of the formation of the financial support infrastructure for innovative activities remains open: the Small Business Innovation Fund has not started to operate due to lack of funds in the budget, the Innovative Industrial Bank went bankrupt and was denied a license in 2012.

8. Increase the efficiency of research and development at universities. Stimulating grants for research. We should mention Horizon 2020 (Seventh Framework Program successor) and Erasmus+ (preceded by Tempus, Erasmus Mundus) of the European foundations. Important European and American organizations are CRDF, CNRS, CERN, and NATO. The German Service of Academic Exchanges (DAAD), the Societies named after Leibniz (WGL) and named after Max Planck (MPG) are worth mentioning separately. Fulbright Ukraine is well known among students and scholars. Ukraine has to pay its contributions to participate in many international projects. Today it is often not feasible for the domestic budget. Thus, as a result of the negotiations conducted by the Ministry of Education and Science, our European partners have agreed that Ukraine can pay only $5 \%$ of the contribution for six years after joining Horizon 2020. It is about 2,8 million dollars for the current rate. The most flexible grant system associated with high school is offered by DAAD. A participant can get an individual scholarship and start a UkrainianGerman Master's programme.

In the short-term, it is necessary to identify instruments that will not burden the state budget and can provide fast and visible results:

1. To develop and implement national support programmes for patenting of Ukrainian inventions abroad and to facilitate access to information on foreign patent bases for all interested economic entities. For Ukraine, the most promising is the provision of the complete technological cycle or turnkey services (like the world Accenture). It is urgent to switch from exporting brains to exporting projects and products. Ukraine has significant potential in the field of AgroTech, including combination with robotics, artificial intelligence, as well as Big Data, and their monetization, in particular, Data Science тa Machine Learnings.

2. Programmes to support commercialisation of the potential of R\&D, start-ups, spin-offs, and SMEs, like Internationalisation Vouchers.

3. Science-industry mobility schemes. The scheme as a whole takes the form of a state subsidy of 1 to 2 years for researchers wishing to develop a research project in partnership with a company that also contributes through its private funds.

4. Cooperative projects between the public research sector and industry.

Author Contributions: conceptualization, O. L.; methodology, O. L.; software, T. M. and A. M.; validation, T. M. and A. M.; formal analysis, O. L., T. M., A. M., L. A.; investigation, O. L.; resources, O. L., T. M., A. M.; data curation, O. L., T. M., L. A., A. M.; writing-original draft preparation, T. M. and A. M.; writing - review and editing, T. M.; visualization, T. M. and A. M.; supervision, O. L.; project administration, O. L.; funding acquisition, O. L., T. M., A. M. 
Liubkina O., Murovana T., Magomedova A., Siskos E. \& Akimova, L. Financial Instruments of Stimulating Innovative Activities of Enterprises and Their Improvements

\section{References}

Andersson M, Karlsson C. (2002). Regional innovation systems in small and medium-sized regions: a critical review and assessment. Jonkoping International Business School, Jonkoping University, 1-650.

Azgaldov G., Kostin V. (2008). Intellectual property, innovation and qualimetry. Economic Strategies, 2 (60), 162-164.

Blind, K., Petersen, S., Riilo, C. (2017). The impact of standards and regulation on innovation in uncertain markets. Research Policy, 46(1), 249-264. https://doi.org/10.1016/j.respol.2016.11.003.

Doloreux D., Parto S. (2015). Regional innovation systems: Current discourse and unresolved issues. Technology in Society, 27, 133-155

European Innovation Scoreboard 2016. European Commission, 2016. Retrieved from http://ec.europa.eu/DocsRoom/ documents/17822.

Fagerberg J., Mowery D., Nelson R. (eds.) (2014). Innovation: A Guide to the Literature. Oxford: Oxford University Press. The Oxford Handbook of Innovation, 2014, 1-26.

Forrester J. (2018). Urban Dynamics. Waltham, MA: Pegasus Communications, 1-300.

Geyets V. (Ed.) (2015). Innovation Ukraine 2020: national report. NAS of Ukraine, 336 p.

Hagerstrand T. (2017). Innovation Diffusion as a Spatial Process. Chicago: University of Chicago Press, 1-350.

Innovative Activity of Industrial Enterprises of Ukraine (2017). Analytical information sheet of the State Statistics Committee of Ukraine. Retrieved from http://www.ukrstat.gov.ua/druk/publicat/kat_u/publnauka_u.htm.

Investigation of Innovation Activity in the Ukrainian Economy (by International Methodology) (2016). Scientific and Innovative Activities of Ukraine: Statistical Collection. State Committee of Statistics of Ukraine, 179-226.

Izsak K., Markianidou P., Radosevic S. (2013). Lessons from a decade of innovation policy. European Commission, 1-100.

Jantsch E. Technological planning and social futures (2012). N.Y.: John Wiley, 2012, 1-423.

Jong M., Marston N., Roth E., Biljon P. (2013). The Eight Essentials of innovation performance. McKinsey \& Company.

Retrieved from https://www.mckinsey.com/ /media/mckinsey/dotcom/ client_service/strategy/pdfs/the_eight_essentials_of_ innovation_performance.ashx.

Maillat D, Ke'bir L. (2001). Conditions-cadres et competitivite des regions: unerelecture. Canadian Journal of Regional Science, 24(1), 41-56

Morris L. (2013). How to Innovate: The Innovation Process. Retrieved from http://www.innovationmanagement.se/ 2013/08/08/how-to-innovate-the-innovation-process.

Nieminen J. (2018). Innovation Management - The Complete Guide. Retrieved from https://www.viima.com/blog/innovationmanagement.

Nieschlag R., Dichtl E., Hans H. (2002). Marketing Gebundenes, Buch, 1-451.

Norek T. (2013). The effectiveness of innovative processes implemented by the SME companies. Results of the empirical research. ACTA Universitatis Agriculturae et Silviculturae Mendelianae Brunensis, volume LXI, 7, 2577-2585. Retrieved from https://acta.mendelu.cz/media/pdf/actaun_2013061072577.pdf

OECD Main S\&T Indicators (2016). OECD, Paris, 1-96.

Reguia C. (2014). Product Innovation and the Competitive Advantage. European Scientific Journal, 1. Retrieved from https://eujournal.org/index.php/esj/article/view/3634.

Science, Research and Innovation Performance of the EU (2018). European Commission. Retrieved from https://ec.europa.eu/info/sites/info/files/srip-report-full_2018_en.pdf.

Statistics on research and development (2019). Eurostat. Retrieved from https://ec.europa.eu/eurostat/data/database.

Stryha M. (2016). Legislative support for the development of the national innovation system: the state and ways of solving. Information and analytical materials for hearings in the Committee of the Verkhovna Rada of Ukraine on issues of science and education, $1-46$.

The Dealbook of Ukraine (2018). Ultimate Report on Ukraine's Venture Investment IT Industry. Retrieved from https://www.slideshare.net/YevgenSysoyev/the-dealbook-of-ukraine-2018-edition.

The global competitiveness report (2018). World Economic Forum. Retrieved from http://reports.weforum.org/globalcompetitiveness-report-2018/

The Global Innovation Index (2017). Retrieved from https://www.globalinnovationindex.org/gii-2017-report.

The Global Innovation Index (2018). Cornell University, INSEAD, and the World Intellectual Property Organization. Retrieved from https://www.wipo.int/publications/ru/details.jsp?id=4330/

Ukraine. Innovation and entrepreneurship ecosystem diagnostic (2017). The World Bank Group. Retrieved from http://documents.worldbank.org/curated/en/126971509628933853/pdf/2-11-2017-14-55-6-

UkrainelnnovationandEntrepreneurshipEcosystemDiagnostic.pdf.

Ukraine. Intellectual property and technology transfer regulatory review (2017). The World Bank Group. Retrieved from http://documents.worldbank.org/curated/en/133701509628796923/pdf/120864-WP-PUBLIC-

UkraineIPandTTRegulatoryReview.pdf. 
Liubkina O., Murovana T., Magomedova A., Siskos E. \& Akimova, L. Financial Instruments of Stimulating Innovative Activities of Enterprises and Their Improvements

Ukraine. Science, technology, and innovation public expenditure analysis (2017). The World Bank Group. Retrieved from http://documents.worldbank.org/curated/en/314581509695378056/pdf/120888-2-11-2017-14-58-48-UkraineSTlexpenditureanalysi s.pdf.

Voynarenko M., Dzhuliy L., Kuzmina O., Yanchuk T. (2017). Managing the development of innovation business processes with automated information systems. Innovation Marketing and Management, 4. Retrieved from http://mmi.fem.sumdu.edu.ua/ sites/default/files/mmi2017_4_133_1 48.pdf

Zizlavskiy O. (2013). Past, Present and Future of the Innovation Process. International Journal of Engineering Business Management Retrieved from https://journals.sagepub.com/doi/full/10.5772/56920.

Zhylinska O., Vakulenko V. (2014). Innovation as a Strategic Factor of Raising the Competitiveness of National Economy. Journal LAssociation 1901 «SEPIKE». Ausgabe 4. 280-284.

О. Любкіна, к.е.н., доцент, Київський національний університет імені Тараса Шевченка (Україна);

Т. Мурована, к.е.н., доцент, Київський національний університет імені Тараса Шевченка (Україна),

А. Магомедова, к.е.н., Київський національний університет імені Тараса Шевченка (Україна);

E. Сискос, д.е.н., профресор, Університет Західної Македонії (Греція);

Л. Акімова, д.держ.упр., доцент, Національний університет водного господарства та природокористування (Україна).

Фінансові інструменти стимулювання інноваційної діяльності підприємств та їх удосконалення

У cmammi проаналізовано значення інновацій як одного з основних факторів впливу на конкурентоспроможність підприємств та економік країн світу. В основу дослідження покладено авторські емпіричні дослідження, засновані на методології аналізу емпіричних даних. Опитування проводилося серед юридичних осіб та їх окремих підрозділів, які здійснюють діяльність незалежно від iї типу. Метою дослідження було визначити важливість фрінансових фракторів у обмеженні інноваційної діяльності та їх потенціал у стимулюванні інноваційної діяльності підприємств. Було проведено опитування підприємств щодо фракторів, які суттєво вплинули на їхнє рішення розвивати інноваційні проекти або стримувати реалізацію інноваційної діяльності. Проаналізовано основні проблеми інноваційної діяльності підприємств (правові бар'єри, бар'єри зі сторони пропозиції, бар'єри зі сторони попиту, бар'єри при взаємодії попиту та пропозиції, відсутність чітко визначених пріоритетів, проблеми комерціалізації результатів науково-технічної роботи, а також слабкий розвиток інфраструктури, трудові проблеми). Дослідження проводилося також шляхом вивчення особливостей застосування фрінансових інструментів стимулювання інноваційної діяльності підприємств, аналізу економічних показників, що характеризують інноваційну діяльність підприємств, аналізу сильних та слабких сторін інноваційних проектів, а також удосконалення фрінансових інструментів стимулювання запровадження інновацій на підприємствах. На основі проведених досліджень визначено довго-, середньо- та короткострокові напрями фрінансової підтримки інноваційної діяльності. На основі проведеного аналізу удосконалено фрінансові інструменти стимулювання інноваційної діяльності підприємств на основі врахування соціальноекономічних, політичних та інших особливостей розвитку країни, у якій запроваджуються такі проекти, дослідження досвіду запровадження реальних інноваційних проектів, аналізу сильних та слабких сторін цих проектів, доцільності реалізації подібних проектів в таких умовах.

Ключові слова: інновації, інноваційна екосистема, інноваційна діяльність, інвестиції, моделювання інноваційних процесів, фінансові інструменти.

Manuscript received: 10.06.2019.

(C) The author(s) 2019. This article is published with open access at Sumy State University. 